\title{
Physicochemical Analysis of Underground Water in Zaria Metropolis, Kaduna State, Nigeria
}

\author{
Apampa Sulaiman Ayodeji", Salisu Abubakar, Eze Samuel \\ Department of Chemistry, School of Secondary Education, Science, Federal College of Education, Zaria, Nigeria
}

Email address:

ayodejialal2000@gmail.com (A. S. Ayodeji)

${ }^{*}$ Corresponding author

To cite this article:

Apampa Sulaiman Ayodeji, Salisu Abubakar, Eze Samuel. Physicochemical Analysis of Underground Water in Zaria Metropolis, Kaduna State, Nigeria. American Journal of Chemical Engineering. Vol. 5, No. 6, 2017, pp. 158-162. doi: 10.11648/j.ajche.20170506.17

Received: August 14, 2017; Accepted: August 28, 2017; Published: November 28, 2017

\begin{abstract}
This study indicates the physicochemical analysis of borehole water in Zaria metropolis of Kaduna State. 25 boreholes were used which were randomly selected. The study areas include Zaria city, Sabon-Gari, Jos road, Danmagaji, and GRA Zaria and a total of 25 water samples from the pumped boreholes water were collected from these areas and labeled $\left(\mathrm{A}_{1}\right.$ $\left.A_{5}\right),\left(B_{1}-B_{5}\right),\left(C_{1}-C_{5}\right),\left(D_{1}-D_{5}\right)$ and $\left(E_{1}-E_{5}\right)$ respectively. The result obtained revealed that: all samples has moderate temperature of $27-29^{\circ} \mathrm{C}$. However, the $\mathrm{pH}$ results showed that only 5 samples were highly alkaline with $\mathrm{pH}$ values above 7.0 while the remaining 20 are slightly acidic. Sample $\mathrm{A}_{5}$ shows the highest electrical conductivity of $1788 \mathrm{Ns}$ while sample $\mathrm{C}_{3}$ and $\mathrm{C}_{4}$ has the least values of 41 us and 37 us respectively. The remaining 22 have irregular conduction values. Similarly, the results of the total hardness show that Zaria city has the highest hardness while Jos road has the least hardness. The remaining 19 show varied hardness. The result of the total dissolved solid (TDS) showed that all the water samples used for this study has little or more dissolved solids with $\mathrm{A}_{5}$ being the highest $(682 \mathrm{mg} / \mathrm{l})$ and $\mathrm{C}_{4}$ the least $(20.2 \mathrm{mg} / \mathrm{l})$. In conclusion, all the borehole samples failed to meet the zero coliform per $100 \mathrm{ml}$ set by WHO. The study therefore recommends that members of these communities should as much as possible ensure they purify their borehole water before consumption.
\end{abstract}

Keywords: Underground Water, Physico-Chemical Analysis, Total Dissolved Solids, pH, Electrical Conductivity, Zaria Metropolis

\section{Introduction}

Water is one of the most important and abundant compounds of the ecosystem. All living organisms on the earth need water for their survival and growth. As of now only earth is the planet having about $70 \%$ of water. But due to increased human population, industrialization, use of fertilizers in the agriculture and man-made activity it is highly polluted with different harmful contaminants. Therefore it is necessary that the quality of drinking water should be checked at regular time interval, because due to use of contaminated drinking water, human population suffers from various water borne diseases. It is difficult to understand the biological phenomenon fully because the chemistry of water revels much about the metabolism of the ecosystem and explain the general hydro -biological relationship [1].
The availability of good quality water is an indispensable feature for preventing diseases and improving quality of life. Natural water contains different types of impurities are introduced in to aquatic system by different ways such as weathering of rocks and leaching of soils, dissolution of aerosol particles from the atmosphere and from several human activities, including mining, processing and the use of metal based materials [2].

The increased use of metal-based fertilizer in agricultural revolution of the government could result in continued rise in concentration of metal pollutions in fresh water reservoir due to the water run-off. Also faucal pollution of drinking water causes water born disease which has led to the death of millions of people [3]. People on globe are under tremendous threat due to undesired changes in the physical, chemical and biological characteristics of air, water and soil. These are related to animal and plants and finally affecting on it [4]. Industrial development (Either new or existing industry 
expansion) results in the generation of industrial effluents, and if untreated results in water, sediment and soil pollution [5] [6].

Having mainly excessive amounts of heavy metals such as $\mathrm{Pb}, \mathrm{Cr}$ and $\mathrm{Fe}$, as well as heavy metals from industrial processes are of special concern because they produce water or chronic poisoning in aquatic animals [7]. High levels of pollutants mainly organic matter in river water causes an increase in biological oxygen demand, chemical oxygen demand, total dissolved solids, total suspended solids and fecal coli form [8].

These contains considerable amount of potentially harmful substances including soluble salts and heavy metals like $\mathrm{Fe}^{2+}$, $\mathrm{Cu}^{2+}, \mathrm{Zn}^{2+}, \mathrm{Mn}^{2+}, \mathrm{Ni}^{2+}, \mathrm{Pb}^{2+}$. Additions of these heavy metals are undesirable. Plants can accumulate heavy metals in their tissues in concentrations above the permitted levels which is considered to represent a threat to the life of humans, and animals feeding on these crops and may lead to contamination of food chain, as observed that soil and plants contained many toxic metals, that received irrigation water mixed with industrial effluent [9].

The quality of ground water depends on various chemical constituents and their concentration, which are mostly derived from the geological data of the particular region. Industrial waste and the municipal solid waste have emerged as one of the leading cause of pollution of surface and ground water. In many parts of the country available water is rendered nonpotable because of the presence of heavy metal in excess. The situation gets worsened during the summer season due to water scarcity and rain water discharge. Contamination of water resources available for household and drinking purposes with heavy elements, metal ions and harmful microorganisms is one of the serious major health problems.

\section{Materials and Methods}

\subsection{Study Area}

The study took place in Zaria city, Sabon Gari, Jos Raod, Dan-Magaji and GRA all in Zaria metropolis area of Kaduna State. The area is characterized by high Temperature of about $29^{\circ} \mathrm{C}-32^{\circ} \mathrm{C}$, and it has an annual rainfall which begins between April and September. The soils of these areas are sandy, welled drained and formed in sandy Loam. The communities are characterized by improper housing sanitation, overcrowding and lack of water supply. The population in each of the communities ranges between 1000 to 2000 .

At each site a sanitary inspection was made during the sampling period. The sanitary inspections involved the use of unstructured questionnaire based on the individual state of the boreholes. At each borehole, twenty five regular users of the boreholes were interviewed. Interviewees were asked about the uses they put the water fetched from the boreholes to. They were asked about their perception on the quality of the water, as well as whether they had experienced any illness they could link to the use of the water in their various activities

A total of 25 water samples from the pumped boreholes water were collected at various locations in Zaria metropolis.
Five different (5) boreholes were selected at each location and were labeled $\left(A_{1}-A_{5}\right),\left(B_{1}-B_{5}\right),\left(C_{1}-C_{5}\right),\left(D_{1}-D_{5}\right)$ and $\left(E_{1}-E_{5}\right)$ each of the samples were represent as:

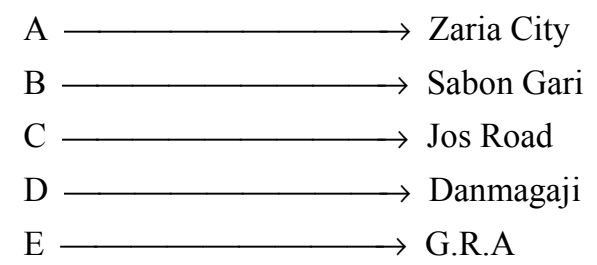

\subsection{Procedure for Physico - Chemical Analysis}

The water samples were collected from all sites in one day (i.e. Monday, $18^{\text {th }}$ April, 2016 from 7am - 10am in the morning. Each sample of water for Analysis was collected using a clean two liter plastic container with a screw cap which was thoroughly washed with detergent and rinse with distilled water.

At the point of collection, the container was rinse three times with the borehole water sample. The initial temps of the sample water were taken. All the samples were collected and stored in the laboratory in a clean place.

The $\mathrm{pH}$ was measured using a digital $\mathrm{pH}$ meter $(\mathrm{HARCH}$ SENSION). The meter was switched on and was allowed to warm for 5 minutes. It was then standardized with a buffer solution. The meter was then immediately introduced into the water sample and measurement was taking after a stable reading was recorded. The electrode was then rinsed with distilled water before taken another measurement.

The temperature was measured at the site of collection using a mobile thermometer. This was done by dipping the thermometer into the water sample for about 5 minutes and recording stable reading.

Electrical conductivities of the water samples were measured using a digital conductivity meter (HARCH Model). An Electrode connected to conductivity meter was immersed into the water sample and a stable reading of each was recorded. The following are the apparatus used;

(i) Retort stand with clamp

(ii) Burette

(iii) Pipette mechanical filter

(iv) Beaker

(v) Buffer solution $\left(\mathrm{NH}_{4} \mathrm{Cl}\right)$.

(vi) Erichrome black. T. indicator

(vii) Measuring cylinder.

$25 \mathrm{~cm}^{3}$ of water sample was pipette into a conical flask. $1 \mathrm{~cm} 3$ of butter solution $\left(\mathrm{NH}_{4} \mathrm{Cl}\right)$ of $\mathrm{pH} 10$ and 3 drops of ferrochrome black. T. indicator were added to the flask. The mixture was then titrated with $0.01 \mathrm{M}$ EDTA (Ethylenediaminetetra Acetic Acid) until the color changed from wine red to blue. The procedure was repeated TWO or more times to obtain the average liter value.

The total dissolved solid was determined using a conductivity meter, the program menu of the conductivity meter was switched to T.D.S; $200 \mathrm{CM}^{3}$ of the sample was measured using measuring cylinder and transferred into a beaker and the electrode was introduced into the sample. The result was displayed and recorded. 


\section{Result and Discussion}

The Parameters Sampling Sites and Result Obtained From Calculations Made

Table 1. Results from Physicochemical Analysis of Underground Water in Zaria Metropolis.

\begin{tabular}{|c|c|c|c|c|c|c|}
\hline S/N0. & Sample Sites & Temperature at Sites $\left({ }^{\circ} \mathrm{C}\right)$ & pH & EC(Us) & TH(Mg/L & TDS (Mg/L) \\
\hline & $\mathrm{A}_{1}$ & 28.0 & 6.86 & 1133 & 432 & 551 \\
\hline & $\mathrm{A}_{2}$ & 28.3 & 7.36 & 372 & 3566 & 182 \\
\hline & $\mathrm{A}_{3}$ & $28^{0}$ & 6.93 & 974 & 3234 & 417 \\
\hline & $\mathrm{A}_{4}$ & 28.7 & 6.60 & 711 & 264.6 & 360 \\
\hline & $\mathrm{A}_{5}$ & 28.0 & 6.84 & 1788 & 384.6 & 682 \\
\hline & $\mathrm{B}_{1}$ & 28.7 & 5.57 & 1014 & 254 & 513 \\
\hline & $\mathrm{B}_{2}$ & 28.0 & 6.21 & 636 & 188 & 328 \\
\hline & $\mathrm{B}_{3}$ & 28.0 & 6.24 & 666 & 147.4 & 329 \\
\hline & $\mathrm{B}_{4}$ & 28.7 & 6.20 & 600 & 145.4 & 322 \\
\hline & $\mathrm{B}_{5}$ & 28.7 & 6.17 & 626 & 135.4 & 282 \\
\hline & $\mathrm{C}_{1}$ & 27.0 & 6.73 & 205.9 & 55.4 & 109.5 \\
\hline & $\mathrm{C}_{2}$ & 27.0 & 5.83 & 76.8 & 14.6 & 45.7 \\
\hline & $\mathrm{C}_{3}$ & 28.3 & 6.21 & 41.8 & 14.0 & 25.3 \\
\hline & $\mathrm{C}_{4}$ & 28.0 & 6.12 & 37.0 & 176.7 & 20.2 \\
\hline & $\mathrm{C}_{5}$ & 28.0 & 6.28 & 77.30 & 34.6 & 44.9 \\
\hline & $D_{1}$ & 27.7 & 6.31 & 324 & 80 & 155 \\
\hline & $\mathrm{D}_{2}$ & 27.3 & 6.48 & 144.2 & 40.6 & 83.8 \\
\hline & $\mathrm{D}_{3}$ & 28.0 & 6.52 & 209.6 & 59.4 & 110.4 \\
\hline & $\mathrm{D}_{4}$ & 28.3 & 6.46 & 465 & 120.6 & 236 \\
\hline & $\mathrm{D}_{5}$ & 27.3 & 6.27 & 289.8 & 80.6 & 1603 \\
\hline & $E_{1}$ & 28.0 & 6.97 & 269.7 & 97.4 & 151 \\
\hline & $E_{2}$ & 29.0 & 7.26 & 439 & 170 & 223 \\
\hline & $\mathrm{E}_{3}$ & 28.3 & 8.00 & 108.5 & 41.4 & 59.3 \\
\hline & $\mathrm{E}_{4}$ & 28.0 & 7.09 & 374 & 136 & 195 \\
\hline & $\mathrm{E}_{5}$ & $28 \mathrm{~S}$ & 7.05 & 377 & 160 & 210 \\
\hline
\end{tabular}

\section{Discussion}

The acceptability and the use of portable water for recreational and other domestic needs is influenced by physico-chemical parameters such as temperature, $\mathrm{pH}$, Electrical conductivity (E.C), Total Hardness, Total Dissolved solids, etc. Inorganic minerals however constitute the greatest source of raw water contaminant of which minerals salts are introduced as the water moves over the soil structure. A major factor affecting water quality is anthropogenic activities arising from rapid urbanization and industrialization [10]. For instance, metals gain access into rivers possibly through anthropogenic and natural sources. Some trace metals are potentially toxics because; they act on the cell membrane or interfere with cytoplasm or nuclear functions after entry into the cell.

Hence their accumulation in the human body could lead to malfunctioning of organs [11]. At high concentrations they cause acute systematic poisons. Use of raw water with high salts results to nauseous saline taste with purgative tendency and dehydration, of great concern are salts containing nitrates and nitrites. These are known to cause Mathaemoglobinemia in children, high fluorides may result in dental fluorosis.

The temperature of sampled borehole water ranges between $28^{\circ} \mathrm{C}-28.7^{\circ} \mathrm{C}$ (at sites of collection) and $34^{\circ} \mathrm{C}-$ $32.7^{\circ} 4$ (i.e. during practical) the mean average values shows that they are within the specification W.H.O of $30^{\circ} \mathrm{C}, 32^{\circ} \mathrm{C}$, and the values are similar to that reported by Obi and Okocha (2007). Cool water are generally more portable for drinking purposes, because high water temperature when cooled enhances the growth of micro-organisms and hence taste, odor, color and corrosion problem may increase.

The $\mathrm{pH}$ value obtained ranged from 6-97-8.00 which shows that almost all the sampled goes beyond the W.H.O recommended value of $(6.5-8.5)$, except in sampling sites of Sabon Gari (B), Jos Road (C) and Danmagaji (D) which are within the W.H.O specification value respectively.

The values are

$\mathrm{B}_{2}=6.21, \mathrm{~B}_{4}-\mathrm{C}_{3}$. The electrical conductivity (EC) of most of the sample fell, within the permissible limit of $500 \mathrm{us} / \mathrm{cm}$ set by W.H.O. Also 10 of the samples increase above the recommended value. These sampling sites include those from Zaria city (A), and Sabon Gari (B) Metropolis. The values are as follows:

$$
\mathrm{A}_{1}=1133 \mathrm{Us}, \mathrm{A}_{3}, \mathrm{~A}_{4}
$$

E.C is an indicator of water quality and soil salinity hence the relatively high value observed in some water samples showed high salinity, thus the water might not Beverly suitable for domestic and agricultural use.

The total Hardness of water is due to the presence of Calciumtrioxocarbonate (iv). The World Health Organization (W.H.O) and international standard for drinking water (1998) classified water with total hardness of $\mathrm{CaCO}_{3}$ less than 
$50 \mathrm{mg} / \mathrm{l}$ as soft water, $50 \mathrm{mg} / \mathrm{l}-150 \mathrm{mg} / 1$ as moderately Hard and water with Hardness above $200 \mathrm{Mg} / \mathrm{L}$ as Hard. Based on these classifications, sampled water from sampling sites of Sabon Gari (B), Danmagaji (D), Jos road (c) and G.R.A (E) are moderately Hard according to the values which are in accordance with W.H.O standard, except for samples in sampling sites $\mathrm{A}_{5}$, and $\mathrm{B}_{1}$ which are Hard Water (i.e. Zaria city and Sabon Gari metropolis). According to the standard of W.H.O. parameters, sampled of borehole water from sampling site of $\mathrm{C}_{2}, \mathrm{C}_{3}, \mathrm{C}_{5}, \mathrm{D}_{2}$ and $\mathrm{E}_{3}$ in sampling site of Jos road, Danmgaji and G.R.A are soft water (W.H.O recommend value). The total dissolved solids (T.D.S $\mathrm{mg} / \mathrm{l}$ ) at the borehole water samples are generally below $250 \mathrm{mg} / 1$ which was within the W.H.O permissible limit for portable water, except for those in Sabon Gari, Zaria city and Danmagaji which do not agree with W.H.O specification value.

\section{Conclusion}

The results showed that shallow boreholes yield water of very poor quality microbiologically. All of the boreholes sampled failed to meet the zero coliform per $100 \mathrm{ml}$ set by WHO (2006). Water quality was inferior when it rained as compared to the dry season. The results from this study clearly demonstrate that the water qualities obtained from shallow boreholes are unfit for human consumption. Certain boreholes have microbiological contamination with the potential for fatal consequences if consumed untreated by humans.

Relying on the natural filtration characteristics of the local soil alone to filter the water as it percolates through the surrounding ground, is clearly insufficient to provide safe potable water for the majority of shallow boreholes which have been documented in this research study. The location and construction play a large part in reducing the contaminations in these boreholes, but do not guarantee that the water obtained from shallow well will be safe to drink. There is an urgent need to develop some form of local treatment to purify shallow boreholes waters for people in the New Jos Road Municipality and other similar places in Zaria Local Government Area of Kaduna State. This will help go a long way to ensure that the Millennium Development Goals (MDGs) are achieved by 2016.

\section{Recommendations}

Groundwater contamination often correlates with areas of poor hygienic standards and sanitation. Minimizing fecal pollution of boreholes within communities must be an integrated approach. Developing sound water resource management programs will be crucial to Ghana's poverty reduction, economic growth, food security and maintenance of natural systems. There is the need for greater community participation in water management in the three communities (Zaria, GRA, Sabon Gari, Dan-Magaji and Jos Road) where the study was conducted.
The following recommendations are made:

1. The State Government should lay more emphasis on water plant building in order to make sure that the water from bore holes produced should be safe for the usage of the community around these area so as to aid the maintenance of healthy living among the people in the community.

2. More surveys of water quality analysis should be carried out in other communities in the municipality.

3. The State Government should provide a fitting water purification method for purifying water from shallow boreholes needs to be developed for the area of study as soon as possible.

4. The Government and NGO's within the study area should ensure that household water treatment such as boiling should be encouraged using different media platforms and village heads before water from these boreholes is used for drinking purposes.

\section{References}

[1] Basavaraja, Simpi, S. M., Hiremath, K. N. S. Murthy, K. N. Chandrashekarappa, Anil N. Patel, E. T. Puttiah, (2011), Analysis of Water Quality Using Physico-Chemical Parameters Hosahalli Tank in Shimoga District, Karnataka, India, Global Journal of Science Frontier, Research, 1(3), pp 31-34.

[2] Adeyeye El, (1994), Determination of heavy metals in Illisha Africana, associated water, soil sediments from some fish ponds, International Journal of Environmental Study, 45, pp 231-240.

[3] Adefemi S. O. and E. E. Awokunmi, (2010), Determination of physico-chemical parameters and heavy metals in water samples from Itaogbolu area of Ondo-State, Nigeria, African Journal of Environmental Science and Technology, 4(3), pp 145-148.

[4] Misra, S. G., Dinesh, D., (1991), Soil Pollution, Ashing Publishing House, New Delhi, India.

[5] Fakayode SO, Onianwa PC (2002). Heavy metals contamination of soil and bioaccumulation in Guinea grass (Panicum maximum) around Ikeja Industrial Estate, Lagos, Nigeria. Environmental Geology, 43: 145-150.n

[6] Fakayode SO (2005). Impact assessment of industrial effluent on water quality of the receiving Alaro River in Ibadan, Nigeria. AJEAMRAGEE, 10: 1-13.

[7] Ellis, K. V., (1989), Surface water pollution and its control" Macmillan press Ltd, Hound mill, Basingstoke, Hampshire RG 21 2xs and London, 3-18, pp 97,100,101 and 208.

[8] Kulkarni, G. J., (1997), Water supply and sanitary engineering. 10th Ed. Farooq Kitabs Ghar. Karachi, 497.

[9] Adnan, Amin, Taufeeq, Ahmad, Malik, Ehsanullah, Irfanullah, Muhammad, Masror, Khatak and Muhammad, Ayaz, Khan, (2010), Evaluation of industrial and city effluent quality using physicochemical and biological parameters, Electronic Journal of Environmental, Agricultural and Food Chemistry, 9(5), pp 931-939. 
[10] Ezeroge, O. U and Ubala. A. O., (2004), Studies on the Effect of Abattoir and Industrial Effluent on the Heavy Metals and Microbial Quality of Aba River in Nigeria. African Journal of biotechnology, 4 (3), pp. 266-272.

[11] Jarup, L. (2003). Hazard of heavy metal contamination. British Medical Bulletin, 68, 167-182.
[12] Obi, C. N and Okocha C. O., (2007), Microbiological and physicochemical analysis of selected borehole waters. Journal of engineering and applied science.257:920-929. 